SUMEDHA-Journal of Management

Referred Journal of CMR College of Engineering $\mathcal{E}$ Technology

January-March 2020, Volume 9, No. 1, pp 79-90

ISSN: 2277-6753 (Print) ISSN: 2322-0449 (Online)

http://cmrcetmba.in/sumedhal

DOI: https://doi.org/10.46454/sumedha/9.1.2020.6

\title{
Employee Well-Being - A Path to Redefine Workplace
}

\author{
Ms. Anitha. $\mathrm{K}^{*}$, V. Shanthi** \\ * Assistant Professor, Ph.D. Research Scholar, Department of Management Studies \\ https://orcid.org/0000-0002-1940-2101 \\ ** Principal, Faculty of Humanities E Science, https://orcid.org/0000-0002-6416-6291 \\ Meenakshi Academy of Higher Education and Research, Chennai. \\ anitharamesh211@gmail.com; vairavanshanthi@gmail.com
}

\begin{abstract}
Globally business senses that they need to harmonise the interest of their people rather than looking only into profits. On this aspectorganisations come across contemporary challenges and ceaseless competition on a day to day basis.Organisations try out varied solutions to equipE sustain in the cut-throat competitive environment. Solutions arise from innovations and employee workforce should be skilled enough to accept those changes. The ultimate concern for organisations is performance and it can be achieved only when employees are committed in their work and loyal to the organisation.Skilled employees play a vivid role in organisational growth and they form the base for an organisation's competitive advantage. In the fast-paced technologically innovated workplace identifying skilled employees $\mathcal{E}$ retaining them will pave a way for sustainable growth. Employee wellbeing is considered important to both employees (in maintaining own health) and the managers as the adverse effect of poor well-being in organisations will lead to negative performance.Employee well-being practices and defining the workplace according to the constructs of the organisation will enhance the employee organisational commitment. With the advent of technological inventions one such solution to enhance employee well-being in organisations would be implementing Artificial Intelligence in the organisations. The study wasconducted among 72 IT employees. The paper implements regression and hierarchical regression analysis to test the facilitated relationship.This study therefore highlights the importance of identifying employee well-being as a sustainable practise for better efficiency and how Artificial intelligence impacts the relationship to get the sustainable organisational commitment. Keywords:Employee well-being, organisational commitment,Artificial Intelligence
\end{abstract}

JEL classification :I300, O33, I310

Publishing Chronology Paper Submission Date : NOVEMber 10, 2019;

PAPER SENT BACK FOR ReVISION :

DeCEMber 2, 2019;

Paper Acceptance Date :

JANUARY 8,2020

Cite this Article as follows as per APA:

K, A., \& Shanthi, V. (2020).

Employee Well-Being - A Path to Redefine Workplace. SUMEDHA JOURNAL OF MANAGEMENT, 9(1), 64. doi:10.46454/sumedha/ 9.1.2020.6 
Employee Well-Being - A Path to Redefine Workplace Ms. Anitha. $K^{*}$, Dr. V. Shanthi**

\section{INTRODUCTION}

Businesses strive day by day to sustain in its environment. Gaining sustainable development within this competitive environment organisations need to continuously improve in their performance \& growth. To achieve this elevated performance organisations need to strengthen its human resources. Human resource management is deliberated as a strategic solution to uplift organizational performance through organization capability (Katou, 2010; Chang and Huang 2005). Few researchers have recommended that a complete planning of HR practices with business strategy will empower organizations to accomplish its desired performance level and competitive advantage (Wright and McMahan, 1992; Chang and Huang, 2005; Chan and Mak, 2012; Altarawneh and Aldehayyat, 2011).Pfeffer, (2010)refers that sustainable HR practices have been familiarised recently by the organisations as they have started to try out numerous strategies to combat the sustainability in the competitive market. On this context the authors have urged Employee well-being as a sustainable HR practice to attain organisational commitment.

Employee Well-being is becoming the buzzword of global confront 2020. It is being valued and is gaining momentum in all organisations to sustain organisational effectiveness. Employee well-being and organisational commitment are the essential root cause for any organisational success. British Psychological Society in the year 2010 has well established the importance of psychological well-being of employees \& how it impacts the organisational success (Sandilya and Shahnawaz, 2018).In simple, workplace well-being is a sense of contentment that an employee feels when he/she is at work. It is a state of mental \& physical feeling that an employee is secured to work at.

On the other side, Organizational commitment is a multidimensional construct says (Walker and Boyne 2005), connecting an employee's loyalty to the organization, although, some research works compact with both terms as synonymous. According to Northcraft, (1996), commitment is an attitude imitating an employee's loyalty to the organization, or as Robbins (2005) says, is the degree to which an employee recognises with a particular organization and its goals, and wishes to sustain membership in the organization.

Both organisational commitment \& employee well-being can be enhanced through technological innovations. These innovations do not follow any such globally accepted metrics. Advancement can be of any way; this paper highlights the importance of Artificial intelligence in moderating the relationship between the two. By adopting such new technologies, to build trust, McKinsey (2017) recommended that companies must connect with employees to know about their apprehensions about working with advanced technologies as the adoption of the technology will require many employees to reskill. Artificial intelligence (AI) is one suchinstrument which uses human intelligence in various grounds and progress the performance, and it is an incipient technology which is used by almost all organisations today to improve productivity and performance Brouwer(2015). Artificial intelligence is providing various solutions to the management right from hiring tools, training \& development and retention of employees. 
Employee Well-Being - A Path to Redefine Workplace Ms. Anitha. $K^{*}$, Dr. V. Shanthi*

\section{STATE OF ART}

\section{Employee Well-Being}

Human Resource practices are now marching their search in encouraging employee wellbeing among the organisations (Beer 2015). Guest and Conway (2004) define wellbeing in terms of six constructs including: a practicable workload; personalcontrol over the job; care from colleagues and supervisors; positive relationships atwork; a reasonably clear role and a sense of control of involvement in changes in theorganisation. The concept of employee wellbeing at work promotes advantages to organizations of having a healthy workforce (Cooper and Robertson, 2001). Fisher (2003)in his study stated that managementrealized that satisfied and healthy employees subsidise the organizational productivity than others. This facilitates that employee wellbeing has substantial impact on performance and survival of organizations in different ways. Currie (2001) views employee wellbeing at work as the physical and mental health of the workforce. Warr (1987) defines well-being more broadly as the overall quality of an employee'sexperience and functioning at work. It encompasses the physical, emotional \& financial strength of employees.

\section{Organisational Commitment}

Organisations are seeking for skilled workforce and are in the talent hunt race to hire the equipped one. In an exertion to retain employees who establish high levels ofperformance, organizations are willing to nurture positive organizational attitudes likejob satisfaction and organizational commitment (Griffith, 2000). The concept has fascinated more consideration in the recent times from researchers, due to globalisation changes in employment practices (Sullivan and Arthur, 2006). Previous research studies have shown that employees' organizational commitment is derived from their perception of the degree to which the employer is committed to and supportive of them (Rhoades \&Eisenberger, 2002; Zhang \& Liu, 2011; DeConinck, 2011), in assisting them to the work-life balance. Fraser \& Hodge (2000)argue that organisational commitment predicts satisfaction.It can be clinched that organisational commitment is one of the striving variable to consider if an organisation wants to have a sustainable workforce.

Research studies have consistently found that both organizational commitment and job satisfaction are noteworthy predictors of employee turnover (Kammeyer-Mueller, Wanberg, Glomb, \& Ahlburg, 2005). It can be rightly said from the above literature that organisational commitment plays a vital role for the organisation to sustain in the environment.Researches have also indicated that one of the most important antecedents of commitment is positive work experiences, particularly those reflecting support on the part of the target (Meyer and Allen, 1991, 1997). It is therefore logical to assert that support for employees' basic psychological needs, and satisfaction of these needs in turn, would be associated with commitment. Only one study to date (Meyer, Stanley, \& Parfyonova, in press) has examined commitment, need satisfaction, and well-being together in one study, and it focused exclusively on organizational commitment. On this context the below hypothesis is framed. 
Employee Well-Being - A Path to Redefine Workplace Ms. Anitha. K*, Dr. V. Shanthi**

H1-Employee Well-beingis positively related to Organizational Commitment.

\section{Artificial intelligence}

The term artificial intelligence was first introduced by John McCarthy in 1956 in his first academic conference on the subject.Research papers have not yet evidenced ant metrics for technological inventions. In this competitive scenario there is a paradigm shift towards artificial intelligence for sustainable HRM practices. Adams (2017) suggests that there should be systematic study of artificial intelligence on basis of nation. Merlin \& Jayam (2018) in their research paper focus that Artificial Intelligence tries to bring out innovative changes in HRM practices like recruitment, training, talent management \& retentionand its role more significantin future. Research studies by D.Wilfred (2018) prove that artificial intelligence provides other benefits in the screening, engagement of the candidate, re-building relationship, post job offer letter, on-boarding, these all empowered and sharpen the recruitment process more effective and efficient, build a reputation for the employer.Kolbjornsrud, Amizo\& Thomas (2016)reviewed the fact that artificial intelligence will soon be able to do the administrative tasks thatconsume much of managers' time faster, better and at lower cost.On this context the below hypothesis was framed.

H2 - Artificial Intelligence moderates the relationship between employee well-being as a HR practice \& Organizational Commitment.

\section{Conceptual Framework}

Conceptual framework sets the stage for the presentation of the particular research question that drives the investigation being reported. (McGaghie, 2001). The independent variable of the study is employee well-being, which is supposed to affect organizational commitment as a dependent variable, and is being influenced by Artificial Intelligence, the moderating variable as shown in figure (1).

Figure 1: Relationship between Employee Wellbeing \& Organizational Commitment through Artificial Intelligence

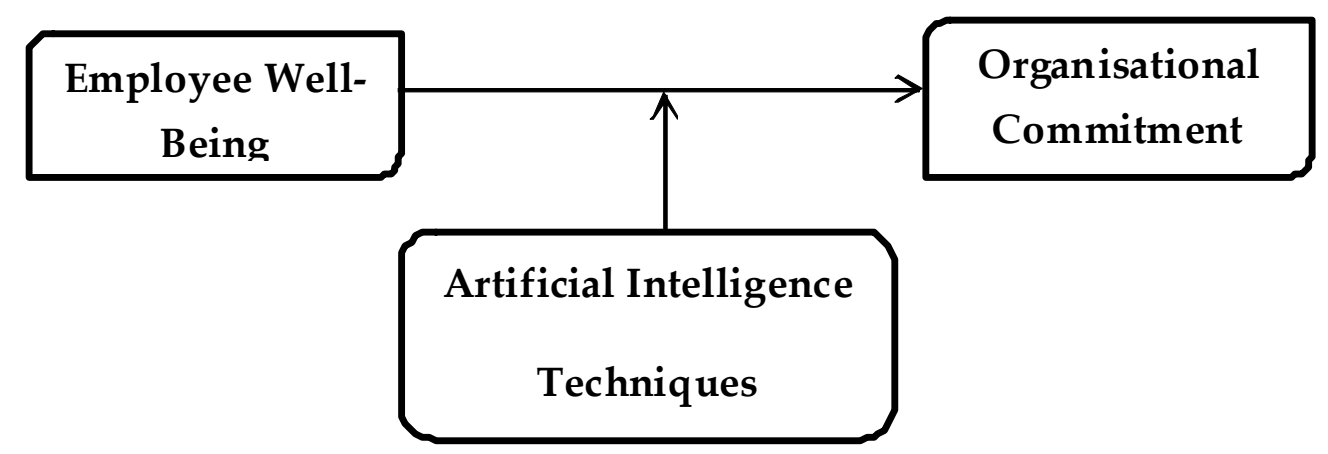




\section{PROBLEM STATEMENT}

Though organisations are facing a ceaseless competition globally, there are few challenges which they need to figure out so that they can sustain in the competitive environment. In order to provide insights to the above statement the authors have taken this research in hand. To be more specific, the following research questions needs to be addressed.

1. What would be the relationship between Employee Well-being and Organizational Commitment?

2. What is the effect of Artificial intelligence in Employee Well-being \& Organizational Commitment?

With the above research questions \& literature review, the hypotheses were framed.

\section{Methodology}

The data for the research was collected from a total of 72 samples using questionnaire. All samples were people working in IT industry.The typical method for collecting demographic details of the sample as well as for administration of questionnaire was implemented to accumulate applicable data for the research. The organisational commitment questionnaire was adapted from Meyer \& Allen (1984) and Employee Well-being was adapted from (General Health Questionnaire). Statistical regression \& hierarchical regression analysis was conducted using IBM SPSS 23.The data collected, was imperilled to reliability test utilizing Cronbach's Alpha which was above 0.60.The numeric results of reliability test are revealed in Table 1.

Table 1: Cronbach's AlphaReliability test

\begin{tabular}{|c|c|c|}
\hline Instruments & Cronbach's Alpha & No.of Items \\
\hline $\begin{array}{c}\text { Employee Well-Being } \\
\text { as a HR Practice }\end{array}$ & 0.822 & 5 \\
\hline $\begin{array}{c}\text { Organizational } \\
\text { Commitment }\end{array}$ & 0.797 & 7 \\
\hline Artificial Intelligence & 0.864 & 5 \\
\hline
\end{tabular}

\section{Research Analysis}

The detailed descriptive analysis of the respondents is shown in Table 2. 
Table 2: Descriptive analysis of Respondents

\begin{tabular}{|c|c|c|c|}
\hline Items & Description & Frequency & Percentage \\
\hline Age & $\begin{array}{l}21-30 \\
31-40 \\
41-50 \\
\text { Above } 50\end{array}$ & $\begin{array}{l}43 \\
27 \\
2 \\
0\end{array}$ & $\begin{array}{l}59.7 \\
37.5 \\
2.8 \\
0\end{array}$ \\
\hline Gender & $\begin{array}{l}\text { Male } \\
\text { Female }\end{array}$ & $\begin{array}{l}42 \\
30\end{array}$ & $\begin{array}{l}58.4 \\
41.6\end{array}$ \\
\hline $\begin{array}{r}\text { Educational } \\
\text { qualification }\end{array}$ & $\begin{array}{l}\text { Diploma } \\
\text { Under graduate } \\
\text { Post graduate } \\
\text { Doctorate } \\
\end{array}$ & $\begin{array}{l}0 \\
47 \\
25 \\
0 \\
\end{array}$ & $\begin{array}{l}0 \\
65.3 \\
34.7 \\
0 \\
\end{array}$ \\
\hline $\begin{array}{l}\text { No. of year you } \\
\text { have been } \\
\text { working in the } \\
\text { current } \\
\text { organization }\end{array}$ & $\begin{array}{l}\text { Less than } 6 \text { months } \\
1 \text { year } \\
2-3 \text { years } \\
3-5 \text { years } \\
\text { More than } 5 \text { years }\end{array}$ & $\begin{array}{l}1 \\
14 \\
27 \\
18 \\
12\end{array}$ & \begin{tabular}{l|l|}
1.3 \\
19.5 \\
37.5 \\
25 \\
16.7
\end{tabular} \\
\hline $\begin{array}{c}\text { How often your } \\
\text { organization } \\
\text { doesconducta } \\
\text { wellness } \\
\text { program? }\end{array}$ & $\begin{array}{l}\text { Once in six month } \\
\text { Once in a while } \\
\text { Yearly } \\
\text { Very rare } \\
\text { Never }\end{array}$ & $\begin{array}{l}57 \\
5 \\
8 \\
2 \\
0\end{array}$ & $\begin{array}{l}79.1 \\
6.9 \\
11.1 \\
2.7 \\
0\end{array}$ \\
\hline
\end{tabular}

To test the first hypothesis regression analysis was facilitated. The authors have chosen regression analysis as it best recognizes the changes in each independent variable and are related to the changes in dependent variable.

H1-Employee Well-beingis positively related to Organizational Commitment.

Table 3: Regression analysis between Employee Well-Being and Organisational Commitment

\begin{tabular}{|l|l|l|l|l|l|}
\hline Independent variable & \multicolumn{1}{|c|}{$\mathbf{R}^{\mathbf{2}}$} & $\begin{array}{c}\text { Adjusted } \\
\mathbf{R}^{\mathbf{2}}\end{array}$ & $\mathbf{F}$ Value & $\begin{array}{c}\text { Beta } \\
\text { Value }\end{array}$ & Signif icance \\
\hline Employee Well-Being & .751 & .751 & 1.341 & .867 & .000 \\
\hline
\end{tabular}

The results pertaining to table 3 shows that oninvestigation of the standardized beta coefficients, it is found that employee well-being is significant and positively influences organisational commitment.The reason may be that healthy employees tend to work more effectively \& efficiently for the organisation. As the literature suggest, results also pertain 
that concentrating on employee well-being \&measure taken to enhance their well-being will eventually improve their commitment towards the organisation which will be helpful to sustain in the competitive environment.

The authors have chosen hierarchical regression analysis to test the next hypothesis.

$\mathbf{H}_{2}$ - Artificial Intelligence moderates the relationship between employee well-being as a HR practice \& Organizational Commitment.

Table 4: Hierarchical regression analysis of Employee Well-Being on the interaction between work Organisational Commitment and Artificial Intelligence.

\begin{tabular}{|c|c|c|c|c|c|c|c|}
\hline Steps & $\begin{array}{c}\text { Independent } \\
\text { Variables }\end{array}$ & $\mathbf{R}^{2}$ & \begin{tabular}{|c|} 
Adjusted \\
$\mathbf{R}^{2}$ \\
\end{tabular} & \begin{tabular}{|c|}
$R^{2}$ \\
Change
\end{tabular} & $\begin{array}{c}\mathbf{F} \\
\text { Change } \\
\end{array}$ & $\begin{array}{c}\text { SigF } \\
\text { Change }\end{array}$ & $\begin{array}{c}\text { Beta } \\
\text { Value }\end{array}$ \\
\hline Step 1 & $\begin{array}{l}\text { Employee Well- } \\
\text { being } \\
\text { Artificial } \\
\text { Intelligence }\end{array}$ & .751 & .751 & .751 & 1341.10 & .000 & $\begin{array}{l}.867^{* *} \\
- \\
0.42^{* *}\end{array}$ \\
\hline Step 2 & $\begin{array}{l}\text { Employee Well- } \\
\text { being* } \\
\text { Artificial } \\
\text { Intelligence }\end{array}$ & .753 & .752 & .002 & 3.203 & .074 & .863 \\
\hline
\end{tabular}

Step 1 regression results in table 4 presents that there is a significant effect between Employee Well-Being, Organisational Commitment \& Artificial Intelligence. Adjusted R2 is .751 and the model is fit as indicated by the significance of $F$ value (1341.105); $\mathrm{p}=.000$; ? coefficient is $.867^{* *}$ for Employee Well-being and $-0.42^{* *}$ for Artificial Intelligence. Employee Well-Being has a significant positive effect and Artificial Intelligence is negatively related to Organisational Commitment.

On analysis of the moderating effects in step 2, adjusted R2 $=.752$; $\mathrm{R} 2$ change $=.002$; $\mathrm{F}$ change $=$ 3.203; Sig F change $=.074$. $R 2$ change specifies that there is advancement in the $\mathrm{R} 2$ value when the 2 nd predictor is added in the 2nd step.

The $R 2$ change is tested with the $F$ change. It is found that $F$ change is significant ( $p=.074)$. A significant $\mathrm{F}$ change indicates that there is momentousenhancement in the prediction by the moderating variable. The model is found to be fit for the significant effect as well as for the moderating effect model. 
Employee Well-Being - A Path to Redefine Workplace Ms. Anitha. K*, Dr. V. Shanthi**

\section{Findings \& Discussion}

The study was conducted among $65 \%$ of under graduates and $35 \%$ of post graduate professional who are aware of artificial intelligence. It is observed that almost $80 \%$ of the organisations conduct employee wellness programmes to know about the present health condition of the employees.Employee health is considered to besupporting aspect of employee well-being (Danna \& Griffin, 1999). Artificial Intelligence analyses the mental health of the employees and gives a clear report on the status of employee health on a daily or monthly basis. Dr. Cooper is a chatbot assistant which easily supports employees on their requests related to well-being. Cogito is another AI assistant which identifies hassled employees through speech recognition. With this technological advent HR people can identify the cause of stress and immediate action can be implemented for the upward mobility of employees. Happy employees in the organisation will have the desire to perform better. Moodkit, Woebot \& Wysa are mental health bots which identifies behavioural changes in an employee. By this organisations can implement essential solutions to overcome the indefinite situations.Therefore, the application of Artificial Intelligence in enhancing employee wellbeing will positively influence organisational commitment.

PERSOLKELLY's 2019 H2 APAC Workforce Insights exposed that augmented use of automation and artificial intelligence at the workplace has a noteworthy effect in increased employee satisfaction. This satisfaction can be brought in highlighting the importance of employee well-being in organisations. This study results the positive impact of employee well-being on organisational commitment.Employees will feel the sense of staying safe when someone is taking care of their health and would be really happy if it's their employer. Happy employees tend to make their employees happy too. This will be concealed in their effective and efficient working which improves their organisational commitment.Reviews on MetaAnalysis on organisational commitment validates that employees who are committed to the organization for which they work do not leave the organisation (Mathieu \&Zajac, 1990; Tett\& Meyer, 1993), attends work regularly (Meyer, Stanley, Herscovtich, \&Topolnytsky, 2002), perform effectively and efficiently (Cooper-Hakim \&Viswesvaran, 2005; Riketta, 2002), and tries to a be good organizational citizens (Meyer et al., 2002; Riketta, 2002).Hence, employee well-being is to be considered as sustainable HR practice to enhance organisational commitment.

Ehnert (2009) in her research argues that sustainable HR model is that which envisions on the changed effects of implementing a policy and gains organizational success in social and environmental scopes.On this aspect the authors have found that employee well-being will be a sustainable HR practice as it exerts positive influence on organisational commitment and through artificial intelligence it can be accomplished effectively and efficiently.

\section{RESEARCH IMPLICATIONS}

With the results it's obvious that every organisation should head towards employee care and should take appropriate steps to enhance employee well-being practices in the company for 
a sustainable organisational growth. This will overlay a way to redefine the entire workplace with commitment and loyalty thus achieving the competitive advantage globally.

\section{LiMIATIONS OF THE STUDY}

This study purely focused on the employee group of IT sector based on Chennai. This study can be observed in different cities with the larger sample.

\section{FUtURE SCOPE OF THE STUdY}

The recommendation for future authors is the investigation of variables in the context of other cities other than Chennai can be done. Other moderating variables on technological advancements can also be included in the study. The relationship of variables also can be examined from a different perspective.

\section{Co NCLUSION}

It was found in the study that lack of prioritising the work, lack of employee engagement, workplace relationships, safety, mental health stressors were the key factors which affects employee well-being at the workplace. This can be sorted out through AI where monitoring an employee round the clock will serve to help him feel better. To understand better a smart watch insisting on the number of calories burnt can trigger a person on his health caution. Similarly at workplace various AI softwareswhich can be implemented to analyse the mood of the employee. For instance,

- Ambera chatbotidentifies happy and unhappy employees.

- $\quad$ Qlearsiteis an engagement survey which provides feedback on a dashboard.

- $\quad$ Sidekick assists employee on personal conversations.

- Humanyzeis a smart badge which collects data about an employee throughout the day on how he worked/collaborated with his peer employees.

- Orion Lab's Panic Bot will identify a hazard for an employee and informs teammate on it. In this way employee feels safe.

Many researches have been conducted linking commitment and employee well-being (Meyer \& Maltin, 2010).This study focused on the same link but with an impact of AI on it. Workrelated mental health issues have become a concern for businesses today. Through technological innovations especially Artificial Intelligence has the potential to help in the workplace expressively as a support system. Therefore, employee well-being can be considered as a sustainable HRM practice to gain organisational commitment.

\section{Authors Contribution}

Ms.Anitha.K and Dr.V.Shanthi framed the theoretical context. Ms.Anitha.K further carried out the study and analysed the data with SPSS tool. Ms.Anitha.K wrote the manuscript along 
Employee Well-Being - A Path to Redefine Workplace Ms. Anitha. $K^{*}$, Dr. V. Shanthi**

with the guidance of Dr.V.Shanthi. Both the authors take the privilege in conceiving the study and were in charge of overall direction and planning.

\section{CONFLICT OF INTEREST}

The authors endorse that they have no affiliations with any organization with any financial interest, or non-financial interest in the subject matter discussed in this manuscript.

\section{Funding ACKNOWLEDgement}

The authors received no financial support for the research, authorship, and/or for thepublication of this article.

\section{REFERENCES}

[1]. Altarawneh, I. I., \&Aldehayyat, J. S. (2011). Strategic human resources management (SHRM) in Jordanian hotels. International Journal of Business and Management, 6(10), 242.

[2]. British Psychological Society (2010) White paper- Psychological well-being at work -. Working group on health and well-being in the workplace. REP94/11.2010.

[3]. Chan, S. C., \&Mak, W. M. (2012). High performance human resource practices and organizational performance: The mediating role of occupational safety and health. Journal of Chinese Human Resources Management, 3(2), 136-150.

[4]. Chang, W. J., \& Chun Huang, T. (2005). Relationship between strategic human resource management and firm performance: A contingency perspective. International journal of manpower, 26(5), 434-449.

[5]. Cooper, C. L., \& Robertson, I. (Eds.). (2001). Well-being in organizations: a reader for students and practitioners. Wiley

[6]. Cooper-Hakim, A., \&Viswesvaran, C. (2005). The construct of work commitment: Testing an integrative framework. Psychological Bulletin, 131, 241-259.

[7]. Currie, D. (2001). Managing employee well-being. Chandos Publishing

[8]. DeConinck, J. B. (2011). The effects of leader-member exchange and organizational identification on performance and turnover among salespeople. Journal of Personal Selling and Sales Management. 31(1), 21-34

[9]. D.Wilfred (2018), AI in recruitment" SAGE Publications, Retrieved from. https://doi.org/10.1177/ 0974173920180204

[10]. Ehnert, I (2009),Sustainable Human Resource Management: A Conceptual and Exploratory Analysis From a Paradox Perspective, Berlin: Physica-Verlag

[11]. Fraser, J., \& Hodge, M. (2000). Job satisfaction in higher education: Examining0020 'gender in professional work settings. Sociological Inquiry, 70, 172-187.

[12]. Friedman, D. E., \& Johnson, A. A. (1997). Moving from programs to culture change: The next stage for the corporate work-family agenda. In S. Parasuraman\& J. H. Greenhaus (Eds.), Integrating work and family: Challenges and choices for a changing world (pp. 192-208). Westport, CT: Qurom Books.

[13]. Guest, D. and Conway, N. (2004), Employee WellBeing and the Psychological Contract: A Research Report, CIPD, London.

[14]. Katou, A. A. (2012). Investigating reverse causality between human resource management policies and organizational performance in small firms. Management Research Review, 35(2), 134-156. 
Employee Well-Being - A Path to Redefine Workplace

Ms. Anitha. K*, Dr. V. Shanthi**

[15]. Kammeyer-Mueller, J. D., Wanberg, C. R., Glomb, T. M., \&Ahlburg, D. (2005). The role of temporal shifts in turnover processes: It's about time. Journal of Applied Psychology, 90, 644-658.

[16]. Kolbjornsrud, V., Amizo, R. and Thomas, J. R., "How Artificial Intelligence will Redefine Management", Harvard Business Review, 2016, 2-6.(poojatripathi, 2012 ).

[17]. Lio, Kutsai. (1995). Professional orientation and organizational commitment among public employees: an empirical study of detention workers. Journal of Public Administration Research and Theory, 5, 231-246.

[18]. Lyubomirs, S. (2001). Why are some people happier than others? The role of cognitive motivational processes in well-being. American Psychology

[19]. Mathieu, J. E. \&Zajac, D. M. (1990). A review and meta-analysisof the antecedents, correlates, and consequences of organizational commitment. Psychological Bulletin, 108 (2), 171 - 194. 11.

[20]. Meyer, J. P., \& Maltin, E. R. (2010). Employee commitment and well-being: A critical review, theoretical framework and research agenda. Journal of Vocational Behavior, 77, 323-337.

[21]. Meyer, J.P., Stanley, L.J., \&Parfyonova, N.M. (in press). Employee commitment in context: The nature and implications of commitment profiles. Journal of Vocational Behavior.

[22]. Meyer, J. P., \& Allen, N. J. (1991). A three-component conceptualization of organizational commitment. Human Resource Management Review, 1, 64-89.

[23]. Meyer, J. P., \& Allen, N. J. (1997). Commitment in the workplace: Theory, research, and application. Thousand Oaks, CA: Sage.

[24]. Meyer, J. P., Stanley, D. J., Herscovitch, L., \&Topolnytsky, L. (2002). Affective, continuance and normative commitment to the organization: A meta-analysis of antecedents, correlates, and consequences. Journal of Vocational Behavior, 61,20-52.

[25]. Northcraft, T. \&. (1996). Organisation Behaviour. London: Prentice-Hall. Sandilya, G. \& G.

[26]. Rhoades, L. \&Eisenberger, R. (2002). Perceived organizational support: A review of the literature. Journal of Applied Psychology, 87, 698-714

[27]. Riketta, M. (2002). Attitudinal organizational commitment and job performance: Ametaanalysis. Journal of Organizational Behavior, 23, 257-266.

[28]. R. M. P and R. Jayam, Artificial Intelligence in Human Resource Management, Int. J. Pure Appl. Math., vol. 119, no. 17, pp. 1891-1895, 2018

[29]. Robbins, S. P. (2005). Organizational Behavior. New York: Pearson Prentice Hal

[30]. Sandilya, G. \& G. Shahnawaz (2018). Index of Psychological Well-being at Work- Validation of Tool in the Indian Organizational Context. Vision-The Journal of Business Perspective - April 2018. DOI: $10.1177 / 0972262918766134$

[31]. Tett, R. P., \& Meyer, J. P. (1993). Job satisfaction, organizational commitment, turnover intention, and turnover: Path analyses based on meta-analytic findings. Personnel Psychology, 46, 259-293.

[32]. Walker, R.M., and G.A. Boyne, (2005), Public Management Reform and Organizational Performance: An Empirical Assessment of the UK Labour Government's Public Service Improvement Strategy. Working Paper, Center for Local and Regional Government Research, Cardiff University

[33]. Wright, P. M., \& McMahan, G. C. (1992). Theoretical perspectives for strategic human resource management. Journal of management, 18(2), 295-320.

[34]. Zhang, J., \& Liu, Y. (2011). Antecedents of work-family conflict: Review and prospect. International Journal of Business and Management, 6(1), 89-103 
Employee Well-Being - A Path to Redefine Workplace

Ms. Anitha. K*, Dr. V. Shanthi**

WEBSITES

1. https://economictimes.indiatimes.com/small-biz/hr-leadership/leadership/the-future-is-now-thechanging-role-of-hr/articleshow/68229542.cms?from=mdr

2. https://www.citrix.com/blogs/2020/02/06/how-ai-could-benefit-mental-health-and-well-being-in-theworkplace/

3. https://www.sapappcenter.com/en/product/display-0000020765_live_v1

\section{About the Author}

Mrs.Anitha.Kis an Assistant Professor, Ph.D Research Scholar in Department of Management Studies, Meenakshi Academy of Higher Education. She has more than 2 years of Academic Experience \& more than 5 year of corporate industry experience. Her research interest lies in the areas of Work-life Balance, Sustainable HR Practices \& Artificial Intelligence. She has published articles in peer reviewed journals and attended various national \& international conferences.

Dr. V. Shanthi is the Principal of Faculty of Humanities \& Science, Meenakshi Academy of Higher Education. She has more than 30 years of Academic experience where she has published more than 50 articles in Scopus Indexed \& Web of Science Journals where she gained more than 359 citations. Her area of interest lies in Artificial Intelligence and has guided M.Phil \& Ph.D Research scholars in her career 